\title{
Active Learning as a Key to Students' Success: An Overview from Students and Lecturers' Perception
}

\author{
Gita Mutiara Hati ${ }^{1}$, Rudi Afriazi ${ }^{1}$ \\ ${ }^{1}$ Faculty of Teacher Training and Education, University of Bengkulu, Jalan WR Supratman, \\ Bengkulu 38371, Indonesia.
}

\begin{abstract}
Over the past decades, the education paradigm in Indonesia has been shifting from the teacher-centered to the student-centered learning, including in higher education institutions. In student-centered learning (SCL), students are expected to be independent, active, as well as to be responsible for their own learning progress. The right implementation of SCL will bring active learning to not only inside but also outside the classroom. The University of Bengkulu shows its high commitment in achieving a high quality of education by organizing a training focusing on the implementation of active learning called ALIHE (Active Learning in Higher Education). However, this training is only for lecturers, not for the students. Meanwhile, the students who are actually the subject of the teaching and learning process do not get similar training. There is therefore a need to develop a similar program for students. This paper serves as a preliminary study in developing a training program of active learning for freshmen university students. It discusses the needs analysis from the students and lectures perspectives, covering: 1) students' learning strategies, 2) students' interest in learning, 3) students' learning difficulties, and 4) lecturers perception toward active learning. At the end of the paper, the implication of the result of this study is discussed.
\end{abstract}

Keywords: active learning; perception; needs analysis; university students

\section{INTRODUCTION}

In a teaching and learning process, it is very common that the teacher dominates the process by simply trying to explain everything to the students. It is due to the belief that by explaining, students will be able to understand the materials being taught. In other words, the teachers think that when they are teaching then it means that students are learning. Moreover, students also assumed that if they have read, paid attention to the teacher, and remembered important points in learning then they can say that they have already learned something [1].

However, this kind of explanation method is not really effective to be applied in the classroom. Most students still do not understand the materials being explained which 
results in the students' failure and negative attitude [2]. They also withdraw themselves from the learning activities, and even fall asleep in the classroom [3]. Thus, the education paradigm has shifted from teacher-centered to students-centered learning.

Students-centered learning (SCL) is a learning approach which places students as main subjects in the teaching and learning process. Students are expected to be independent and active learners, as well as responsible for their own learning [2]. In SCL, teachers are not merely teaching, instead they are facilitating students to make their own interpretation toward the materials being learned. Teachers also guide students to use strategies most useful for them. As a result, students will be creative, innovative, effective, efficient, as well as confident learners. Learning activities are designed in such a way that enables students to think, not only listening to teachers' explanations [4]. The right implementation of SCL will bring active learning into the classroom in which students discover the meaning of learning through actively involve themselves in class discussions, learning activities, and group work [4].

Active learning in the classroom encourages students to actively take initiatives in discovering knowledge [5]. It also gives chances to students to experience a meaningful learning [6], because in active learning students optimally use their brains in reviewing learning materials, solving problems, and implementing the knowledge they have gained [7]. The roles of teachers are even more important since they are required to creatively design the teaching and learning processes along with the activities which promote active learning. If active learning is well designed, the students will likely to have more chances to develop their physical and psychological potential into maximum level.

Trainings and seminars have been conducted by the government for the teachers with the hope that active learning becomes the school learning culture. Not only schools, universities also eagerly support active learning in the teaching and learning process. University of Bengkulu for example, has been conducting a training focusing on active learning called ALIHE (Active Learning in Higher Education) for lecturers of not only University of Bengkulu but also other universities in the city. With this training, it is expected that the lecturers will apply active learning in their own classrooms.

However, implementing active learning in the classroom it is not as simple as it seems. Although teachers have been trained several times, the implementation of active learning is not quite satisfying. The old explanation method is still used in the teaching and learning processes [8]. Therefore, it is a need to share the knowledge and implementation of active learning not only to the lecturers but also to the university students. The students need to become independent and successful learners since in this era of globalization, strong competitiveness power is highly required.

One solution offered to overcome this problem is to develop a model of Active Learning Training Program for freshmen university students. This kind of training is hopefully useful for the students during their education in the university. If they are equipped with this training, it is expected that they will become independent long-life learners. In order to develop this training model, a preliminary study covering the needs analysis is needed. Therefore, the objective of this paper is to discuss the following: 1) students' learning strategies, 2) students' interest in learning, 3) students' learning difficulties, and 4) lecturers perception toward active learning. 


\section{METHODS}

This study employed a descriptive quantitative design. It involved lecturers and students from five universities in Bengkulu City: University of Bengkulu, University of Dehasen, University of Prof.Dr. Hazairin, Islamic State Institute of Bengkulu, and Muhammadiyah University. The lecturers and students participated in this study were chosen randomly from faculties which were also randomly selected from each university. The faculties list can be seen in Table I.

TABLE I. LIST OF FACULTIES

\begin{tabular}{|cc|}
\hline University & Faculty \\
\hline University of Bengkulu & Teacher Training and Education \\
Mathematics and Science & Engineering \\
University of Dehasen & Teacher Training and Education \\
Lniversity of Prof. Dr. Hazairin & Teacher Training and Education \\
& Economics \\
Islamic State Institute of Bengkulu & Tarbiyah and Tadris \\
& Syari'ah \\
Muhammadiyah University & Economics \\
& Engineering \\
\hline
\end{tabular}

Two different sets of questionnaire were developed, one for the students and one for lecturers. The questionnaire for the lecturers was only to collect the data regarding their perception toward the implementation of active learning. As for the students, the questionnaire was developed based on the following aspects: 1) students' learning strategies, 2) students' interest in learning, and 3) students' learning difficulties. The data was then analyzed quantitatively and was interpreted in order to meet the objective of the study.

\section{RESULT AND DISCUSSION}

Results of this study are discussed based on the aspects developed in the questionnaire for lecturers and for students:

\section{Lecturers' Perception toward the implementation of Active Learning}

The questionnaire developed for the lecturers consists of sixteen statements trying to elicit their perception toward the implementation of Active Learning in the university. It is a closed-questionnaire four options: SA (Strongly Agree), A (Agree), NA (Not Agree), and SNA (Strongly Not Agree. The choice of SA and A represents positive perception, while NA and SNA means that the perception is negative. 
The analyzed data is interpreted as in Table II.

TABLE II. LECTURERS RESPONSES TO THE QUESTIONNAIRE

\begin{tabular}{|cc|}
\hline University & Responses \\
\hline University of Bengkulu & Positive \\
University of Dehasen & Positive \\
University of Prof. Dr. Hazairin & Positive \\
Islamic State Institute of Bengkulu & Positive \\
Muhammadiyah University & Positive \\
\hline
\end{tabular}

It is evident that lecturers form all universities involved in this study have positive perception toward the implementation of active learning. Basically, they agree to the opinion that the implementation of active learning gives chances to students to understand more the learning materials. When the active learning is implemented, they see that many students are more skillful in communicating their opinion and argument. Responses from the lecturers also reveal that they believe that students have to be active in getting deep understanding concerning the learning materials. It means that they should actively questioning the lecturers, finding other resources instead only listening to the lectures, and participating in a class discussion as well. These findings support the definition from Prince [9] who states that active learning is not merely asking students to do their homework, instead it is actually the activities designed to be implemented in the classroom in order to encourage students' activity and involvement in the learning process.

Another statement in the questionnaire which most lecturers agree with is 'Students' are more confident in asking and answering questions in the implementation of active learning'. When teachers constantly implement active learning in their classroom, it is no doubt that students have more chances to be involved in the learning process. Even in a traditional lecturing, students may be forced into active learners if they are asked to jot down questions during lecture, given set of questions to be answered within the lecture, or frequently asked to make connections between previous and recent materials [10]. Hence, it makes them get used to share their opinion and argue to others opinion.

In addition, the results also show that most lecturers agree to the opinion that active learning is very suitable for university students. University education requires students to survive three to four years education experience and to apply their knowledge in a broader context in a society after they graduate. In order to achieve that, students need to start learning actively during their study [10]. Implementing active learning in the university will not only help students with the improvement of their GPA but also with their determination to stay in the curriculum [11]. 


\section{Students' Learning Strategies}

The first part of the questionnaire for students covers 25 statements describing the learning strategies which characterized the active learning. Students were asked to respond Yes if the statement best suite their condition. They can choose No if the statement does not describe their usual strategy of learning. TABEL III shows the percentage of those strategies used by the students.

TABLE III. STUDENTS' LEARNING STRATEGIES

\begin{tabular}{|cc|}
\hline University & Active Learning Strategies Used (\%) \\
\hline University of Bengkulu & 61 \\
University of Dehasen & 64 \\
University of Prof. Dr. Hazairin & 67 \\
Islamic State Institute of Bengkulu & 62 \\
Muhammadiyah University & 58 \\
\hline
\end{tabular}

It can be seen that the highest percentage of strategies used by the students is only $61 \%$. It means that they are actually implementing strategies which can be categorized as active learning. The use of these strategies by the students is perhaps encouraged by the lecturers who have been trained on active learning. However, it is not enough. They need to implement all these strategies fully in order to be active learners.

One statement which is interesting and in fact many students choose Yes to it is " $I$ prefer the lecturer explains the materials than to have to look for it by myself". This clearly shows that the students are passive learners. This way of learning will not likely get the students anywhere. They are waiting to be spoon-fed, just sitting in the classroom listening to the lectures. This type of learning may be resulted from the way the students study at schools. Meanwhile, being university students is a different thing. They need to be prepared to be successful learners. Successful learners will have bigger chance to have successful life in the future.

\section{Students' Learning Interest}

Part two of the questionnaire requires students to respond to ten statements describing their interest in learning. The choices range from SA (strongly Agree), A (Agree), NA (Not Agree) and SNA (Strongly Not Agree). The analyzed data was interpreted as Low learning interest (Mean Score 1-2.9) and High learning interest (Mean Score 3-4) level. Table IV shows the learning interest of students from five universities involved. 
TABLE IV. STUDENTS' LEARNING INTEREST

\begin{tabular}{|ccc|}
\hline University & Mean Score & Level of Interest \\
\hline University of Bengkulu & 2.45 & Low \\
University of Dehasen & 2 & Low \\
University of Prof. Dr. Hazairin & 2.35 & Low \\
Islamic State Institute of Bengkulu & 2.55 & Low \\
Muhammadiyah University & 2.45 & Low \\
\hline
\end{tabular}

The result shown in the table is quite disappointing since it is expected that university students should have high interest in learning. High interest in learning is believed to be contributing to students' academic achievement at schools [12]. Meanwhile, low interest in learning may lead students to failing courses. Active learning is somewhat related to students' interest in learning. When students are given tasks and activities which require them to be active and engaged to the tasks, they will likely to have high interest [13]. High learning interest, at the end, will boost students' academic performance.

It is not surprising, however, to find out that students' learning interest is quite low. This may due to the fact that active learning is not widely and fully implemented in the classroom. When active learning is involved, there will be no room for students to be bored easily. They will be fully engaged in the learning process since they are constantly asked to think, to pose questions, to argue, and to participate in hands-on activities. On the other hand, the interest level is not very low that it needs only little more hard work in the classroom to create interesting learning experiences which will increase their learning interest to the maximum level.

\section{Students' Learning Difficulties}

Part two of the questionnaire for students tries to reveal what difficulties students encounter during their learning. TABLE $\mathrm{V}$ ranks the difficulties students mostly experience.

TABLE V. STUDENTS' LEARNING DIFFICULTIES

\begin{tabular}{|lc|}
\hline \multicolumn{1}{|c|}{ Difficulties } & Occurance (\%) \\
\hline Difficult to learn independently & 37.5 \\
Hard to get deep understanding because of lecturing method & 25 \\
Afraid to be embarrassed when asking questions & 19 \\
Difficult to take responsibility in group work & 12.5 \\
Hard to share opinion in a group work & 6.25 \\
\hline
\end{tabular}

The result shows that apparently many students face the difficulty in learning independently, whereas as university students, they are expected to spend most of their time studying not only in the classroom but also outside the classroom. Learning time in the classroom is limited, so students should be able to manage their time studying independently. Becoming independent learners cannot accomplished by the students 
themselves. They need to be guided by the teachers to learn how to learn. Teachers' role, or lecturers, is definitely not transferring knowledge but creating activities which encourage students to be actively involved in the learning process, thus make the students become lifelong learners [14].

It is also evident from TABLE $\mathrm{V}$ that by lecturing method, students find it difficult to get deep understanding of the learning materials. Unfortunately, lecturing method is still widely used in many university classes. This may be resulted from large size of the classes which makes it more challenging to set up activities which characterize active learning.

\section{CONCLUSION}

Findings discussed above show that lecturers are actually optimistic about the implementation of active learning. However, sometimes it is not supported by the facilities available in the university where they teach. The curriculum and assessment system also not quite appropriate since the grading system is still based on the result of mid-term and final-term exams.

The facts that students' learning strategies have not categorized as the active learning suggest that there is a need to set up a model of training for students to prepare themselves to be active learners. It is also related to their saying that it is difficult for them to study independently and the fact that they have a quite low interest in learning. They need to be guided to learn how to learn, find what strategies best for them.

A model of training program focusing on active learning for freshmen students is considered urgent to be developed. Results gathered in this study will serve as the basis of the development of the program. The framework of the program will be focusing on how to prepare learners to be active, independent, successful long life learners.

\section{REFERENCES}

[1] Wirth, K.R. and D. Perkins. 2008. Learning to learn. Retrieved July 10, 2017, from http://www.macalester.edu/academics/geology/wirth/CourseMaterials.html

[2] Harsono, H. 2008. "Student-centered Learning di Perguruan Tinggi," Jurnal Pendidikan Kedokteran dan Profesi Kesehatan Indonesia, 3(1):4-8.

[3] Garner, B. K. 2007. Getting to Got It: Helping Struggling Students Learn How to Learn. Association for Supervision and Curriculum Development.

[4] Cromley, J. 2000. Learning to Think, Learning to Learn: What the science of thinking and learning has to offer adult education. National Institute for Literacy.

[5] Afriazi, R. 2015. Paketin-man: Pembelajar Aktif yang Kreatif, Efektif, Tangguh, Inovatif, dan Mandiri. Halaman Moeka Publishing.

[6] Warsono, W. \& Hariyanto, H. 2013. Pembelajaran Aktif: Teori dan Asesmen. PT Remaja Rosdakarya.

[7] Silberman, M. L. 1996. Active Learning: 101 Cara Belajar Siswa Aktif. Nusamedia.

[8] Panjaitan, M. O. 2014. "Implementasi Pendekatan Belajar Aktif di Sekolah Menengah Atas, " Jurnal Pendidikan dan Kebudayaan, 20(1).

[9] Prince, M. 2004. "Does Active Learning Work? A Review of the Research," J. Engr. Education, 93(3): 223-231. 
[10] The Florida State University. 2011. Instruction at FSU: A guide to teaching and learning practice. Office of Distance Learning, The Florida State University.

[11] Bullard, L., R. Felder, and D. Raubenheimer. 2008. "Effects of Active Learning on Students Performance and Retention," presented at the Annual Conference on the American Society for Engineering Education, 2008.

[12] Kpolovie, P.J., A.I. Joe, and T. Okoto. 2014. "Academic Achievement Prediction: Role of Interest in Learning and Attitude towards School," International Journal of Humanities Social Science and Education (IJHSSE), 11(1):73-100.

[13] Subramaniam, P.R. 2009. "Motivational Effects of Interest on Student Engagement and Learning in Physical Education: A Review," Int. J. Phys. Educ., 46(2):11-19.

[14] Meyer, W.R. 2010. "Independent Learning: A Literature Review and a New Project," presented at the British Educational Research Association Annual Conference, September 1-4, 2010. 